\title{
Effect of Site Attributes and Matrix Composition on Neotropical Primate Species Richness and Functional Traits: A Comparison Among Regions
}

\author{
Bayron R. Calle-Rendón ${ }^{1,2, *(D)}$, Renato R. Hilário ${ }^{1,2}$ and José Julio de Toledo ${ }^{1,2} \mathbb{C}$ \\ 1 Programa de Pós-Graduação em Biodiversidade Tropical, Universidade Federal do Amapá, Rod. JK Km02, \\ Macapá 68903-419, Brazil; renatohilario@gmail.com (R.R.H.); jjuliotoledo@gmail.com (J.J.d.T.) \\ 2 Laboratório de Ecologia, Universidade Federal do Amapá, Rod. JK km02, Macapá 68903-419, Brazil \\ * Correspondence: brcalle@unal.edu.co
}

Received: 11 April 2019; Accepted: 23 May 2019; Published: 25 May 2019

\begin{abstract}
Fragmentation threatens biodiversity and forest-dwelling animals can be especially vulnerable. Neotropical primates inhabit forests and play ecological roles in maintaining forest biodiversity. Currently, many primate communities are restricted to forest fragments. We (1) evaluated the influence of environmental, matrix, and site attributes on species richness and functional traits of primates in the Neotropics; and (2) evaluated the effect of the sub-region on the relationships between primates and environmental, matrix, and site attributes. We conducted literature searches to find published data on primate communities in forest fragments throughout the Neotropics. Each fragment was assigned to 1 of 11 sub-regions: Mesoamerica, Tumbes-Chocó-Magdalena, Caribbean, Orinoco, Amazon, Atlantic Forest, Cerrado, Chaco, Andes, Caatinga, and Pampa. Based on actual and expected species occurrences, we calculated the proportion of primate species retained in the fragments, the mass retained, and dietary items retained considering reproductive and vegetative plant parts and prey. We used linear mixed models to correlate primate variables with environmental, matrix, and site attributes. Fragment area was more important for primate retention than environmental, matrix, and site attributes, with primate retention being higher in larger fragments. Fragment size was positively correlated with all primate variables, except for retention of prey consumption, whose retention decreased as water bodies and density of buildings in the matrix increased. Fragments within protected areas retained larger species than unprotected fragments. The proportion of extant mass retained and vegetative plant parts in the diet were highest in Mesoamerica and lowest in the Atlantic Forest. Conservation planning of Neotropical primates should consider both the differences among sub-regions, forest restoration to increase fragment size, and the creation of new protected areas, even in fragmented landscapes.
\end{abstract}

Keywords: habitat loss; human presence; matrix; Neotropical sub-regions; primate conservation

\section{Introduction}

The Earth is in the midst of the sixth mass extinction, making strategies for effective biodiversity conservation increasingly necessary [1]. As a key threat to biodiversity, deforestation is still increasing around the world, leading to reduced species richness and impaired ecosystem functions [2,3]. Habitat fragmentation leads to forest patches of different sizes surrounded by a matrix composed of anthropogenic components [4-8]. Forest patches with remaining populations can suffer local extinctions, as population size alone may not guarantee long-term viability, and organisms may not have the ability to leave the patch and travel through the matrix to colonize other forested areas $[3,9,10]$. As moving between patches through the landscape may be necessary to maintain populations, species 
survival may also depend on matrix permeability [11], which can be driven by inherent factors (e.g., climatic conditions, hunting pressure, and differences in agricultural activities) related to regions that host those animals and matrices [12,13].

Although Neotropical primates are primarily forest-dwelling animals, some species are able to use non-forested environments in the matrix for short periods $[14,15]$. Therefore, it is necessary to understand how the matrix (i.e., the nonhabitat surrounding the fragment [10]) is related to primate occurrence. Globally, primate species richness is highest in the Neotropical region, with 171 species distributed from Southern Mexico to Northern Argentina [16]. Primates are important components of forest biodiversity as seed dispersers, pollinators, and modifiers of both nutrient cycling and forest structure [17-20]. As such, primates occurrence is correlated with the species richness of understory plants [21]. Additionally, primates are important both culturally and as a food resource for many ethnic groups [22], and their extirpation from forests could be related to the loss of aboveground forest biomass [23]. Currently, 36\% of Neotropical primates species are threatened and several species are restricted to fragmented landscapes [16].

Studies from fragmented forests in the Neotropical region have shown that fragment size is the primary correlate of primate species richness, abundance, and occurrence $[6,24,25]$. Higher connectivity between fragments is also associated with primate occurrence [26,27]. The intensity of human impacts (e.g., wildfires, timber extraction, hunting, roads, and agricultural fields) has negative effects on the occurrence and population structure of primates in Neotropical fragmented landscapes $[24,28]$.

The common response of primates to habitat loss, fragmentation, and degradation is population decline; however, the persistence of primate species in fragmented landscapes can be mediated by their functional traits [16]. Species with smaller home ranges, smaller body sizes, and lower proportions of fruit in their diet are able to occupy smaller fragments [6,25]. Loss of primates with certain traits could have negative consequences for ecological processes, such as seed dispersal [20]. Loss of Atelids (primates with large home ranges, bigger body sizes, and higher proportions of fruit in their diet) in different Neotropical sub-regions has been shown to affect recruitment patterns of large-seeded species in the Amazon [29], Orinoco basin [30], and Chocó-Darién [31].

Natural variation in primate species richness shows marked differences between Neotropical sub-regions and continents [16,32]. Such differences depend on both biotic and abiotic attributes. Forest structure (biotic attribute) is the main driver of primate diversity in the Neotropics, but precipitation (abiotic attribute) is the main driver in Asia [32]. Environmental conditions inherent to each sub-region can influence the economic, social, political, and cultural context, and consequently modify the nature of matrices that surround forest patches that host primate species [12,33].

Therefore, attributes of the regions need to be considered to make robust primate conservation plans. Whereas large-scale studies have assessed the effect of patch size, fragment age, and connectivity on primates across the Neotropics [34-36], at a continental scale, little is known about the effects of matrix attributes such as length of roads and number of human settlements. Attributes such as these have, at least locally, been shown to affect the occurrence of Neotropical large mammals [37,38]. Notwithstanding protected areas being recognized as preserving primate populations locally $[39,40]$, no large-scale evaluation of their effectiveness for primate conservation has been conducted.

In this study, we aimed to investigate how primate communities respond to matrix components (e.g., human settlements and roads) surrounding the forest fragments, site-level attributes (e.g., forest height, net primary productivity, and protection status), and environmental factors (temperature and precipitation), in the Neotropical region and between Neotropical sub-regions. We evaluated the influence of environmental features, matrix components, and site attributes on species richness and functional traits of primates in the Neotropical region, considering the effect of the Neotropical sub-region on the relationships between primates and matrix components and site attributes. We expected that species retention, especially the larger ones, will be lower in small fragments and in those fragments surrounded by matrices that are more hostile to primates (e.g., more infrastructure and higher roads density) due to smaller population sizes and reduced gene flux, leading to genetic 
deterioration [41,42]. We predicted that primates that consume higher amounts of vegetative plant parts will persist in small fragments due the plasticity in their diet and higher availability of this food item [43]. The same trend may be expected regarding primates that heavily rely on prey, which may benefit from the fact that disturbances in the matrix increase populations of invertebrate prey [44,45]. Retention of reproductive plant part consumption will decline sharply because large-bodied frugivorous primates (e.g., spider monkey) are the first going extinct in small fragments [25]. Finally, we predicted that species persistence will be different among sub-regions due to differences both environmental conditions and species composition, and that fragments within protected areas will retain more species than unprotected fragments.

\section{Materials and Methods}

\subsection{Literature Review}

We conducted literature searches in Web of Science, Scopus, Scielo, and Google Scholar to find studies that reported on primate species composition in forest fragments in the Neotropical region. We used three key words ('primates', 'habitat loss', and 'fragmentation') in English, Spanish, and Portuguese in combination with 19 Neotropical primate genera [46]: Alouatta, Aotus, Ateles, Brachyteles, Cacajao, Callicebus, Callimico, Callithrix, Cebuella, Cebus, Chiropotes, Lagothrix, Leontopithecus, Mico, Oreonax, Pithecia, Saguinus, Saimiri, and Sapajus.

The initial search returned 3491 studies (journal articles, theses, and technical reports) published from 1960 to September 2016. Firstly, duplicates were removed from the 3491 studies, and then the results were filtered based on title alone and the abstract, discarding papers that were clearly unrelated to the purposes of this study. We also discarded studies that did not present sufficient geographical information to identify precisely each forest fragment. The selected studies included data collected through interviews, surveys and behavioral studies (direct observations), playback [36,43], and camera traps in combination with any other method. Studies that used camera traps alone were discarded because they may miss certain primate species, even when they are located on tree branches $[47,48]$. We only included in the analysis forest patches and fragments with an area $\leq 11,570$ ha (hereafter, fragments), including both those from anthropogenically-fragmented forest landscapes and naturally patchy landscapes (e.g., savannas) with anthropogenic components in the matrix. This size was chosen since it is the "minimum area of suitable habitat" for the biggest Neotropical primate (Brachyteles spp.) [49]. Whenever possible, start and ending years of fieldwork were also recorded for each study. At the end of the selection process, a total of 110 studies were found that reported information regarding the primate communities in 512 forest fragments.

\subsection{Geographic Information System (GIS) Analysis}

The coordinates of each selected fragment were uploaded into Google Earth Pro (version 7.1.5.1557; Google Inc., Mountain View, CA, USA). If the image available for the fragment was of sufficiently high resolution, then a polygon was drawn around it to quantify its area and perimeter. We also delineated and removed vegetation-free areas inside the fragments to obtain the real area of forest available for the primates. We used the best image available with the date closest to the year in which fieldwork was conducted. We preferred the use of Google Earth Pro instead of other alternatives for measuring forest cover (e.g., Hansen et al. [2]), because this software provides readily available images covering most of the Neotropical region. Google Earth Pro is a tool that has been used in the classification of landscapes in other studies of Neotropical primates [36,50] and landscape analyses in the Neotropics [51].

For each fragment, we calculated a shape index as:

$$
\text { shape }=\frac{p}{200\left[(\pi A)^{1 / 2}\right]^{\prime}}
$$


where $p$ is the perimeter in meters and $A$ is the area in hectares [52]. A value of 1 indicates a perfectly circular fragment; the higher the value, the more irregular the shape.

Each forest fragment was assigned to 1 of the following 11 Neotropical sub-regions, following author descriptions from the original studies and shapefiles from the Critical Ecosystem Partnership Fund (CEPF) [53] and the Instituto Brasileiro de Geografia e Estatística (IBGE) [54]: Mesoamerica, Tumbes-Chocó-Magdalena (TCM), Caribbean, Andes, Orinoco, Amazon, Atlantic Forest, Cerrado, Caatinga, Pampa, and Chaco. Amazon and TCM are regions dominated by rainforest, although some areas from Peru and Ecuador present other vegetation (dry forest) [55]. Cerrado, Orinoco, and Pampa are predominately areas of savanna and grasses with some forest patches [27,56,57]. Caribe and Caatinga are areas of dry forest $[58,59]$. The Andes region is composed of montane forests in elevations above 1,000 $\mathrm{m}$ in altitude [60]. Atlantic Forest and Mesoamerica include tropical and subtropical forest [61,62], and elevation and latitude determine the vegetation type. Chaco is a forested area in the center of South America, with both dry and wet areas and a dominant vegetation characterized mostly by deciduous trees and shrubs in the dry season [63].

Two fragments at the northern extreme of the TCM sub-region were classified within the Caribbean sub-region as their features are markedly different from those of the TCM in Colombia in terms of precipitation and vegetation, being significantly drier areas [59]. Seven fragments located between the limits of the Andes and TCM sub-regions in Colombia were classified as TCM as they are along the inter-Andean valley of the Magdalena River and are located below 1,000 $\mathrm{m}$ in altitude. Three fragments from Brazil classified as Atlantic Forest by the authors were located in the Cerrado according to the Brazilian biome shapefile [54].

We imported the polygons created in Google Earth into QGIS (version 2.14.8-Essen; QGIS Development Team 2014, Essen, Germany), saved them as a shapefile and re-projected all in WGS84 datum in the Universal Transversal Mercator (UTM) coordinate system. We generated a 1-km buffer from the border of the fragment to characterize the matrix within the buffer, a method that has been used for small mammals and primates in Neotropical studies [7,8,64,65]. We selected this buffer size because it is the mean travel distance in the matrix reported for some Neotropical primates [66-68]. From a landscape perspective, the effect of the matrix considers the fragments size [69]; however, because Neotropical primates are primarily arboreal and non-forested areas outside the fragments are not habitat for them, we preferred a buffer from the fragment perimeter, contrary to a circular buffer as used in the patch-landscape approach [12]. Our objective was to understand how the components beyond the border of the fragment (i.e., where the primates leave the habitat and start a "non-natural" movement) affect the primates.

We exported the buffers to Google Earth Pro and manually classified the areas within the buffer into five types using the 'polygon' tool. We then calculated the percentage of (1) forest vegetation (Ve), as a proxy of functional connectivity since primates can use the non-habitat (matrix), expressing a different movement pattern to arrive to another forest fragment [11]; (2) water bodies (Wa), such as seas, lagoons, and rivers; (3) residential areas (RA), defined as groups of houses forming urban or rural areas; (4) tree and palm plantations (Pl); and (5) non-forested areas (NF) as all those areas without structures of connection for primates. NF specifically included land without vegetation (rocks and beaches) and areas with crops, grass, or savanna. Although some areas such as crops have different effects on primates than open areas because they can serve as source of secondary resources to some primate species [14,15], they are not structures providing connection for Neotropical primates. It is difficult to distinguish those areas using the available images in all the Neotropical regions. We counted the number of isolated individual roofs inside the buffer to calculate the density of buildings (DB) and calculated the length of roads using the 'path' tool to estimate the density of roads (DR). To balance the time taken to conduct the manual classification of the matrix with the number of patches available for the analysis, first, we randomly selected 10 sites per sub-region for classification. For TCM and Chaco, we included all nine fragments that achieved our selection criteria (see below) in each sub-region. For the Atlantic Forest and Mesoamerica, we selected five additional fragments in each sub-region 
given the larger set of fragments available. For the Amazon, we selected 10 additional fragments considering both the larger set of fragments available and the larger extension of the sub-region. We considered the distribution of the sites throughout the sub-regions to include these additional fragments, selecting those fragments located mostly away from other selected sites. Finally, a total of 97 fragments were included in this study from studies conducted between 2000 and 2016 (Table S1).

We extracted data on other predictors from the center of each forest fragment using raster images. We used a global map of forest height $(\mathrm{FH})$ at a $1 \mathrm{~km}^{2}$ spatial resolution [70] as a proxy of vertical forest structure [32]. We downloaded net primary productivity (NPP) data at a $1 \mathrm{~km}^{2}$ spatial resolution from the NASA Earth Observations to represent a measurement of the total amount of carbon dioxide up taken by plants [71]. Because NPP is temporally variable, we used a sequence of raster images of June and December from 2000 to 2010, then we used the sequence to calculate a mean NPP for each fragment over this time period. Finally, we obtained temperature annual range (TAR) and precipitation seasonality (PS) data at $\sim 1 \mathrm{~km}^{2}$ spatial resolution via WorldClim version 2 [72]. To understand the effect of the reserves on primate communities, we identified if each fragment was within a protected area (PA) according to the information from the study site.

\subsection{Primate Variables}

We calculated the proportion of extant species retained for each fragment $(s p)$ as:

$$
s p=s p_{\text {ext }} / s p_{\max }
$$

where $s p_{\text {ext }}$ is the current species richness reported in each fragment and $s p_{\max }$ is the maximal species richness expected, considering the natural geographic distribution of all primate species for each fragment [36], based on distributions from the IUCN (International Union for Conservation of Nature, Red List of Threatened Species) [73] and reports from each study. The genus Aotus was only included in the calculation of $s p_{\max }$ when the study reported its presence, since it is more difficult to detect these nocturnal primates. Introduced or reintroduced primate species were not considered in $s p_{\max }$ or $s p_{\text {ext }}$.

Each primate species was also classified according to an updated list of functional classification of ecospecies [74]. Ecospecies are classifications of platyrrhine primates based on functional traits of species that are ecologically equivalent [75]. This classification allows gathering more information about different taxa to understand the primate response to changes in the habitat [43]. We obtained the body mass of each species from the All the World's Primates database [76]. We used the average value of male and female body mass for those species in which the information was provided separated by sex. For those species without information in that database (13\%), we used the average body mass of the ecospecies [74]. The proportion of extant mass retained $(M)$ was calculated using the following equation:

$$
M=\frac{\sum_{i=1}^{n} m_{i}}{\sum_{j=1}^{N} m_{j}},
$$

where $m_{i}$ is the body mass of species $i$ considering the current species reported in each fragment $(n)$, and $m_{j}$ is the body mass of the species $j$ considering the complete primate assemblage $(N)$ according to the natural geographic distribution of primates for each fragment. As such, $M$ allows "to examine broad patterns of species deletion across the body size spectrum" [36].

To understand the variation in species responses according to diet, we assessed the proportion of the following items in the diet of each ecospecies [74]: (1) reproductive plant parts (diet $t_{R P}$ : fruits, seed, and flowers); (2) vegetative plant parts (diet ${ }_{V P}$ : leaves and buds); and (3) animal prey (diet $t_{P r}$ ) (Table S2). First, the contribution of each ecospecies in a dietary category for each fragment $\left(p_{x i}\right)$ was calculated as:

$$
p_{x i}=\frac{d_{x i}}{\sum_{i=1}^{N} d_{x i}}
$$


where $d$ is the proportion of an item $x(R P, V P$, or $P r)$ in the diet of ecospecies $i$ present in each fragment according to the values from Hawes and Peres [74], and $N$ is the maximal number of species found in the fragment. Finally, for each fragment, the proportion of each extant consumption of a dietary item retained $\left(\right.$ diet $\left._{x}\right)$ was calculated as:

$$
\operatorname{diet}_{x}=\sum_{i=1}^{n} p_{x i}
$$

where $n$ is the number of species found currently in the fragment and $x$ is the item in a dietary category $(R P, V P$, or $P r)$. As the indices related to functional traits used here consider the ecospecies composition, they can provide insights into how the predictor variables operate among the different sub-regions because species composition is different among them.

\subsection{Data Analysis}

We used an ANOVA to test for significant differences in matrix components (Ve, Wa, RA, DB, $\mathrm{Pl}$, and $\mathrm{DR}$ ) and fragment size between sub-regions. We used linear mixed-models (LMM) from the package 'nlme' [77] to analyze the influence of environmental variables (TAR and PS), site (FH, $\ln (\mathrm{NPP})$, shape, $\ln ($ area $)$, and $\mathrm{PA}$ ) and matrix components $\left(\mathrm{Ve}^{1 / 2}, \mathrm{Wa}, \mathrm{RA}, \mathrm{DB}, \mathrm{Pl}\right.$, and $\left.\mathrm{DR}\right)$ on the proportion of species retained $(s p)$ and retention of functional traits $\left(M, \operatorname{diet}_{R P}\right.$, $\operatorname{diet}_{V P}$, and $\left.\operatorname{diet}_{P r}\right)$ considering forest fragments as sampling units. We used LMM to deal with the possible spatial autocorrelation, controlling for the effect of the sub-region by placing it as a random factor, and using the environmental variables, site attributes, and matrix components as fixed factors to test their effect on the proportion of species retained and the ecological characteristics of primates. Only those fragments with $s p_{\max }>1$ and $s p_{\text {ext }} \neq 0$ were included in the analysis. These criteria excluded all fragments from the Pampa sub-region, some from Mesoamerica (El Salvador and the Sumidero canyon in Mexico), all from the Argentinian Chaco, and from the Andes. We used Akaike's information criterion corrected for small samples (AICc) to select the most plausible model for each dependent variable applying the Maximum Likelihood (ML) method in accordance with Zuur et al. [78] and using the package 'MuMIn' [79]. We used a 'Random Intercept Model' instead of a 'Random Intercept and Slope Model' in the LMM [78] due to the large number of explanatory variables and assuming that the rate of the effect of the predictor variables does not change between sub-regions. After, we ran the most parsimonious model applying the restricted maximum likelihood (REML) method [78]. We checked for spatial autocorrelation in the residuals of each most parsimonious model with Moran's I correlograms in the package 'ncf' [80] and detected spatial autocorrelation in all models, at least in the first two distance classes (Figure S1). As such, we then used the 'corr' argument available in the 'nlme' package to create the same models, but adding different classes of spatial correlation structures, such as spherical, exponential, Gaussian, linear, and rational. We used the Akaike's information criterion (AIC) to compare those models applying the ML method. Once the most parsimonious model was chosen (i.e., model with the lowest AIC), we refitted the original model with the spatial correlation structure applying the REML method [78]. Although it was possible to assess the effect of the random factor (i.e., Neotropical sub-region) plus fixed factors (i.e., environmental variables, site attributes and matrix components) on primates using the conditional $R^{2}$ in the LMM [81], the 'Random Intercept Model' does not allow detection of shifts in the slope (i.e., interaction of predictors with sub-region). Therefore, we used ANCOVA's to assess such effects using only predictors detected by our most parsimonious models. All analyses were performed in R software, version 3.5.1 [82]. Because some fragments from Mesoamerica did not provide values for the diet of animal prey due to the presence of species that feed exclusively on plant parts (Alouatta and Ateles), resulting in only three fragments with values for this dependent variable, we excluded Mesoamerica in the model of diet $_{P r}$. In the final database, all but four studies involved direct observation (Table S1); for that reason, we think that detectability is not a problem here. 


\section{Results}

\subsection{Matrix Differences Among Neotropical Sub-Regions}

The 97 fragments selected from 50 studies were distributed in eight minor sub-regions with at least nine fragments per sub-region (Mesoamerica, Tumbes-Chocó-Magdalena, Caribbean, Orinoco, Amazon, Atlantic Forest, Cerrado, and Chaco) (Figure 1, Tables S1 and S3). In these 97 fragments, size ranged between 0.8 and 8897 ha, and varied equally across sub-regions $(F=1.43, p$-value $=0.203)$. The proportion of some matrix components in the 1-km buffer around each fragment differed significantly among sub-regions: forest vegetation $(F=4.887, p$-value $=0.0001)$, water bodies $(F=4.726, p$-value $=0.0001)$, residential areas $(F=3.319, p$-value $=0.003)$, non-forested areas $(F=7.45$, $p$-value $<0.0001)$, density of roads $(F=5.7, p$-value $<0.0001)$, and density of buildings $(F=5.587$, $p$-value $<0.0001)$. Specifically, the highest proportion of forest surrounding the fragments was found in the Amazon sub-region. The Amazon also had the greatest proportion of water in the matrix, mainly due to dams. The Cerrado, Orinoco, and Atlantic Forest sub-regions had a greater proportion of plantations in the buffer area, composed of oil palms and eucalyptus. The Cerrado had the highest proportion of residential areas. The Chaco and Atlantic Forest sub-regions had the highest density of roads and houses (Figure $\mathrm{S} 2$ ).

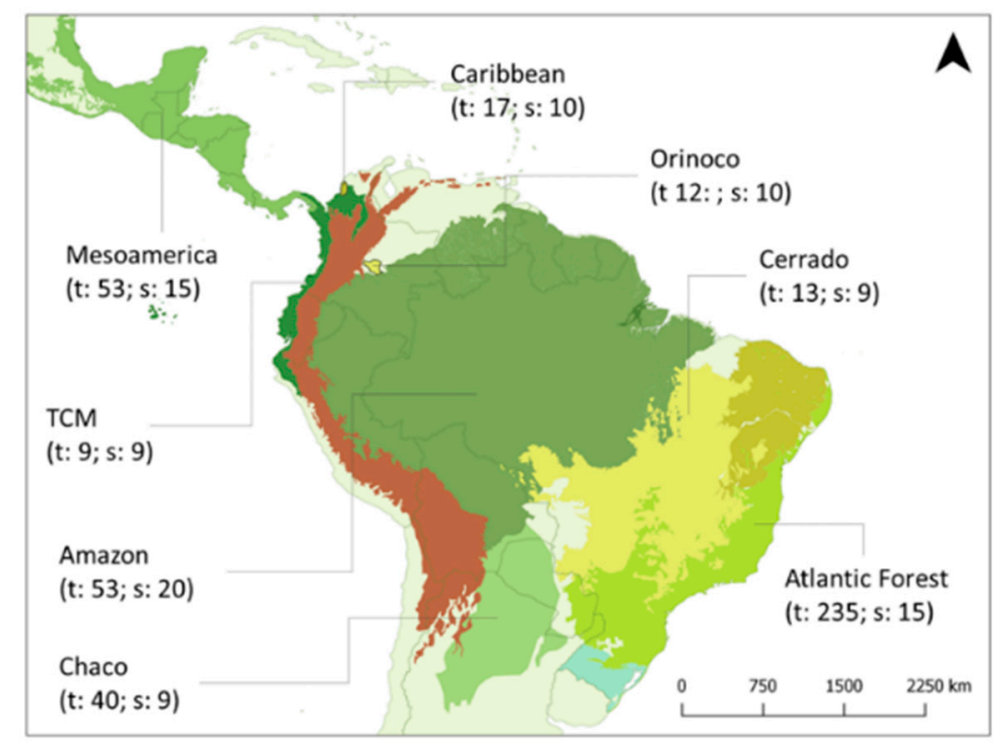

Figure 1. Distribution of the nine sub-regions in the Neotropics, the total number of fragments $(t)$ found in the literature search, and the number of fragments included in our analyses (s) for each sub-region.

\subsection{Effects of Matrix Components, Environmental Conditions, and Site Attributes on Primates}

For species retention and consumption of reproductive parts, the most parsimonious model included only fragment size as predictor, indicating that larger fragments hold a greater proportion of the original assemblages and species with diets composed more heavily of fruits, seeds, and flowers (Table 1). For mass retention, the most parsimonious model included density of buildings, fragment size, and protected areas as predictors (Table 1), indicating that large and protected fragments retain larger species, but increased human presence in the matrix (density of buildings) negatively affects these larger primates (Table 1). The most parsimonious model for consumption of vegetative plant parts indicated a positive effect of fragment size and protected areas (Table 1). Finally, for diets based on animal prey, the best model included density of buildings, fragment shape, and water bodies (Table 1). Thus, retention of animal prey consumption decreased significantly in fragments surrounded by higher proportions of water bodies and increased human presence in the matrix (density of buildings) (Table 1). 
Table 1. Results of model selection using linear-mixed models (LMM) explaining the proportion of species retained and ecological characteristics of primates in forest fragments in the Neotropical region through environment, landscape, and fragment attributes. Marginal $R^{2}$ values $\left(\mathrm{m}^{2}\right)$ only consider fixed effects, and conditional $R^{2}\left(\mathrm{c} R^{2}\right)$ includes both fixed and random effects. $\hat{\alpha}$ and $\hat{\beta}$ are the intercept and slope, respectively, of the fixed effects and $\hat{d}$ is the variance for the random intercept.

\begin{tabular}{|c|c|c|c|c|c|c|c|}
\hline Model & $\mathrm{mR}^{2}$ & $\mathrm{cR}^{2}$ & $\hat{\alpha}$ & Predictors & $\hat{\beta}$ & $p$-Value & $\hat{d}$ \\
\hline$s p^{\mathrm{a}}$ & 0.09 & 0.12 & 0.397 & Area & 0.041 & 0.0005 & 0.041 \\
\hline \multirow[t]{3}{*}{$M^{\mathrm{b}}$} & 0.09 & 0.17 & 0.427 & Area & 0.020 & 0.040 & 0.089 \\
\hline & & & & $\mathrm{DB}$ & -0.009 & 0.055 & \\
\hline & & & & PA & 0.166 & 0.019 & \\
\hline $\operatorname{diet}_{R P}{ }^{\mathrm{c}}$ & 0.09 & 0.09 & 0.364 & Area & 0.044 & 0.0008 & 0.00001 \\
\hline \multirow{2}{*}{$\operatorname{diet}_{V P} \mathrm{~b}$} & 0.09 & 0.28 & 0.402 & Area & 0.037 & 0.001 & 0.147 \\
\hline & & & & $\mathrm{PA}$ & 0.121 & 0.13 & \\
\hline \multirow[t]{3}{*}{ diet $_{P r} \mathrm{~b}$} & 0.12 & 0.12 & 0.590 & DB & -0.022 & 0.045 & 0.000008 \\
\hline & & & & Shape & 0.039 & 0.081 & \\
\hline & & & & Wa & -0.416 & 0.011 & \\
\hline
\end{tabular}

Note: Primate variables are species retention $(s p)$, mass retention $(M)$, species retention with diet of reproductive parts of the plant $\left(\operatorname{diet}_{R P}\right)$, species retention with diet of vegetative parts of the plant $\left(\operatorname{diet}_{V P}\right)$, species retention with diet of preys (diet $t_{P r}$ ). Predictors are density of buildings (DB), water (Wa) and protected area (PA). ${ }^{\text {a }}$ Exponential spatial correlation, ${ }^{b}$ Rational quadratic spatial correlation, ${ }^{\mathrm{c}}$ Spherical spatial correlation.

\subsection{Effect of Sub-Region on the Relationship between Primates and Site and Matrix Attributes}

Results of conditional $R^{2}$ indicated that sub-region plus fragment size had an effect on some primate-site relationships (Table 1), although there were no changes in slope detected by the ANCOVA tests. For species and mass retention, and for retention of diets based on vegetative parts, the proportion of variance explained by fragment size and sub-region (conditional $R^{2}$ ) was higher than the proportion of variance explained only by fragment size (marginal $R^{2}$ ) (Table 1 ). For retention of diets based on reproductive parts of the plant and animal prey, fixed factors explained the same variation as the fixed and random factors together (conditional $R^{2}=$ marginal $R^{2}$ ); values of the variance for the random intercept $(\hat{d})$ were close to zero (Table 1$)$. There was variation among sub-regions in the relationship between fragment size and species retention, mass, and diet based on vegetative plant parts, with the highest variation for diet $(\hat{d}=0.147)$ and lowest for retention of species $(\hat{d}=0.041)$ (Table 1$)$. As such, for the same fragment size, retention of primate attributes would be highest in Mesoamerica and the Amazon, and lowest in the Atlantic forest and Chaco (Figure 2).
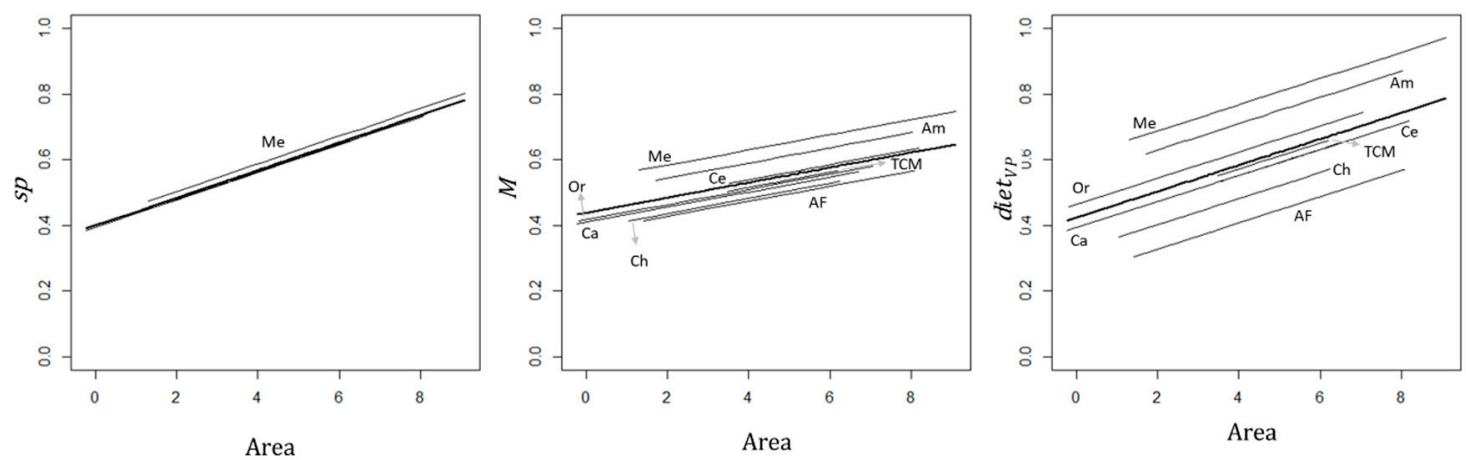

Figure 2. Relationship between species retention $(s p)$, mass retention $(M)$ species retention with diet of vegetative parts of the plant $\left(\right.$ diet $\left._{V P}\right)$ and fragment size $(\ln ($ area $))$. Models are based on a 'Random Intercept Model' using LMM. Thick line represents the fixed component and Neotropical sub-regions are Atlantic Forest (AF), Amazonia (Am), Caribbean (Ca), Cerrado (Ce), Chaco (Ch), Mesoamerica (Me), Orinoco (Or), and Tumbes-Chocó-Magdalena (TCM). 


\section{Discussion}

This is the first study to compare how matrix components, including quantitative measures of anthropogenic attributes and environmental conditions, affect the retention of primates in fragmented landscapes across the Neotropical region. Although matrix composition was included as a potential predictor, a clear general pattern emerged, in which fragment size is a key determinant of species persistence and of the retention of traits of Neotropical primates. We found that primate persistence within forest fragments depends on their functional traits and on inherent aspects of the biogeographic sub-regions.

\subsection{Relationship Between Matrix and Site Attributes and Primate Species Richness and Functional Traits}

Our results show that fragment size was the most important predictor of the retention of primate species in the Neotropical region, which is consistent with previous global and Neotropical analyses for primates and other vertebrates $[34,36,83]$. Larger areas not only support larger primate populations, but also maintain an adequate forest structure [84]. Larger fragments of tropical forest may provide a greater diversity of food resources, different canopy strata, and shelter to support viable populations of different animal species [85]. Larger fragments host more tree species and more stable availability of food resources through the year [85]. Death of larger trees increases sharply along the fragment edges [86] and smaller trees become more frequent in smaller fragments exposed to chronic edge effects [87]. Therefore, in smaller fragments, resource quantity and quality may change dramatically.

Fragment size also explained a significant part of the retention of functional traits of primates. The higher retention of body mass in larger fragments is consistent with previous studies in the Neotropics [36]. As larger species are more prone to local extinctions [88], we expected this pattern from our results. In forest fragments from the Amazon, body mass predicted the occurrence rate of primates [6], suggesting that larger primates need larger areas. Considering the body size spectrum within the forest fragments [36], the smaller fragments are retaining small-sized primate species, and this could have negative consequences for frugivory and therefore for plant diversity. For example, due to the positive correlation between body mass and percentage of frugivory [74], we think that, independent of the ecospecies present in a certain fragment, fruit consumption will be higher where mass retention is higher. Frugivory has connotations for plant species richness. As such, it is expected that larger fragments will have higher species richness than smaller fragments. This pattern was observed in fragments from the Amazon, where a reduction in species richness of seedling communities was detected in smaller fragments [89]. This makes even more sense, since we also detected a positive relationship between fragment size and retention of consumption of reproductive plant parts (fruits, seeds, and flowers). Those fragments within protected areas can retain larger primate species. Protected areas are recognized by their role in maintaining higher abundance and species richness by diminishing forest loss [90,91], and evidence suggests that reserves maintain stable populations of primates by avoiding hunting $[39,40]$.

We found that persistence of folivorous primates was affected by fragment size in all Neotropical regions. Foliage is a resource present in both smaller and larger forest fragments, and its availability do not seem to be limiting for primates in small fragments. Smaller fragments have higher edge effects, allowing herbivores to find plant species with leaves containing higher nutritional quality content [92]. However, habitat loss could be affecting the quantity and quality of other resources that are more variable over time (e.g., fruits), with consequences for primate persistence. The majority of Neotropical primates include certain proportions of leaves in their diets, and even the most folivorous species do not feed exclusively on leaves [74]. The effect of area on the retention of folivorous primates could be a reflection of the loss of primates, such as Alouatta and Brachyteles, since these primates include the largest proportions of leaves, but also fruits, in their diets [74]. Brachyteles spp. for example, is present in the Atlantic Forest, one of the most fragmented regions in the Neotropics [93]. These primates are highly sensitive to habitat loss and showed low occupancy rates in their distribution area [43]. Alouatta spp. is a widely distributed genus, found from Mexico to Argentina. Their species 
are commonly reported to persist in fragmented landscapes and they occupy fragments (even small fragments) throughout the Neotropical region [43]. However, each case regarding this genus needs to be analyzed with caution, as Alouatta has been reported to be locally extinct in some areas, and in others, it is necessary to maintain a minimum fragment size to reduce the extinction probability $[94,95]$. The important issue regarding this relationship is that the reduction in fragment size decreases the diets based on vegetative parts. Therefore, this could reduce ecosystem services provided by primates, such as increase the amount of foliage due the removal of buds and nutrient cycling, with negative effects on the forest structure [19].

Some primates are considered to be 'ecosystem engineers' as they modify plant community structure through their feeding behaviors [19]. Specifically, primates can reduce the reproductive success of some tree species through feeding on flowers [96], or could increase the reproductive success of other plants through pollination [17] and seed dispersal [21], and contribute to nutrient movement within and between habitats through feeding on fruits and subsequent defecation [97]. The higher retention of diets based on reproductive parts of the plant in larger fragments has important implications for seed dispersal and, as such, has key conservation implications. If small areas are retaining fewer primates that feed on plant reproductive parts, there will be a disruption in seed dispersal leading to a decrease in plant species richness in the understory [21,29-31]. Consequently, large forest patches are necessary to maintain these primates and the ecological services they and other species provide [98]. Contrary to the other traits, the retention of prey consumption was not explained by area. Instead, it showed a negative association with the density of buildings. A higher density of buildings may be correlated with more intensive agricultural activities, and this may modify the arthropod communities as a result of increased use of pesticides and fertilizers compared with less densely populated areas $[99,100]$. Another possible reason could be pet-keeping and hunting, as carnivorous and insectivorous primates are represented mainly by Cebids, which are frequently used for those purposes (e.g., Cebus capucinus, Saguinus nigricollis, and Saguinus leucopus as pets; and Cebus kaapori and Sapajus xanthosternos as hunting targets) [101-105]. Although empirical evidence exists to support the idea of negative effects of reservoirs (the main type of water body in our study areas) on primates and other vertebrates [106,107], the negative relationship between area of water bodies in the matrix and diets based in animal prey may also be explained by a negative effect of water bodies on prey species. Invertebrates are the main prey fed upon by Neotropical primates [74], and they are also sensitive to dams and alterations in water flow $[108,109]$.

Other studies have shown that the matrix matters more than fragment size for small mammals [8,64]; however, for some Neotropical primates, the pattern is contrary, and fragment size is more important than components in the matrix [7]. Here, we present empirical support to show that in the entire Neotropical region, fragment size is more important than matrix components for primate species. Nevertheless, fragment size alone should not completely explain how primates are responding to habitat loss, since we detected spatially-structured residuals in the LMMs before adding the spatial correlation structures. This means that other spatially-structured ecological processes or historical events may be influencing the primate populations but not represented by the variables in our analyses [110], such as differences in levels of endemism or beta-diversity as a consequences of geological legacies [111,112]. Hence, large-scale studies should include spatial covariates as surrogates for other ecological processes or historical events because the assemblages of many vertebrates can be more related to spatial effects than environmental conditions [113].

\subsection{Effect of the Neotropical Sub-Region on Primate Species Richness and Functional Traits}

The relationships between fragment size and retention of mass, diets of vegetative parts, and species varied between sub-regions. Although such variation was weak for species retention, this was consistent in a global-scale study in which South America showed higher species richness than Madagascar for a given fragment size, and that species richness in Africa has no significant relationship with fragment size [34]. Primates from Madagascar face a limited dietary quality and this could 
decrease the likelihood of their persistence in small fragments [114]. The non-relationship in Africa is due to the extant taxa being resistant to anthropogenic landscape alterations [34]. These results suggest there are regional mechanisms that act synergistically with the relationship between primate retention and site attributes, such as resource availability and species traits.

We found a general pattern where primates from Mesoamerica seem to be the least sensitive to fragment size changes, and those in the Atlantic Forest, the most sensitive. Although both sub-regions are highly fragmented and have historically coped with habitat loss $[61,62,93]$, they are distinctly different in primate composition. Several species occupy the Atlantic Forest, and large portions of this sub-region (and also the Chaco sub-region) are below the Tropic of Capricorn. Globally, there is a positive relationship between latitude and geographic range of primates (Rapoport effect), but such relation is negative in the Neotropical region [115]. Species of narrow geographic ranges are more prone to extinction [116] and, consequently, those primates from Chaco and Atlantic Forest would be more vulnerable than primates from Mesoamerica. Thus, primates may face some challenges to survive in higher latitudes and fragmentation may be adding to these challenges, leading to a lower retention of primates in small fragments at higher latitudes.

The highest variation between sub-regions was found for the relationship between fragment size and diets based on vegetative parts, and this was mainly due to differences between Mesoamerica and the Atlantic Forest. This may be explained by the greater persistence of Atelids in Mesoamerica. In this sub-region, Alouatta, the most folivorous primate in the Neotropics, is present in $86 \%$ of the fragments, whereas in the Atlantic Forest, Alouatta was reported only in 33\% of the fragments. Brachyteles, another genus that includes large amounts of leaves in its diet, was absent from all fragments in the Atlantic Forest included in our analyses. The pattern in the Chaco was similar to that in the Atlantic Forest, with two species of Alouatta, one of which is locally extinct [95], contributing to the lower retention of the diet based on vegetative parts. The pattern in the Amazon was more similar to that in Mesoamerica, with the sub-region not only having the highest maximum species richness in the Neotropics, but also a fauna including ecospecies with relatively high contributions of vegetative parts in their diets such as howler monkeys (Alouatta, 54\%), Amazonian dusky titi monkeys (Callicebus, 34\%), and tufted capuchins (Sapajus apella, 16\%) [74]. A Neotropical analysis showed that these ecospecies are less sensitive to changes in fragment size (e.g., Alouatta and Callicebus) and have the highest occupation rates (e.g., Alouatta and Sapajus apella) in fragments along their geographic distribution [43]. Mesoamerica, in contrast, although showing lower species richness, hosts Alouatta, the most folivorous genus and the genus most resistant to human alterations [117-119], which could explain the higher retention of diets based in vegetative parts in this sub-region.

Another important variation between sub-regions was observed in the relationship between fragment size and mass, which could also be explained by differences in primate faunas, with less loss of mass in primate communities in the Amazon and in Mesoamerica than in the other sub-regions. In both cases, this is seemingly being driven by the persistence of species of the largest genera including Alouatta and Ateles in both sub-regions, and Lagothrix in the Amazon only. For example, more than $50 \%$ of the analyzed fragments in Mesoamerica retained Alouatta and Ateles, all fragments from the Amazon had Alouatta, and 50\% had Ateles or Lagothrix too.

\section{Conclusions}

Our approach of using functional traits to compare actual and expected species occurrences is useful for evaluations on large scales; however, differences among sub-regions need to be considered. Studies like this could be conducted in other areas such as Africa, clustering fragments into the biodiversity hotspots [120] and ecoregions [121]. Africa (including Madagascar island) has a total of 214 primate species, with more than one-third of them threatened, and with body masses ranging from $0.03 \mathrm{~kg}$ (Madame Berthe's mouse lemur, Microcebus berthae) to $200 \mathrm{~kg}$ (western and eastern gorillas, Gorilla spp.) [16]. Other biological orders could be targeted, since there is information about current occurrence available in published studies, the expected species occurrences using the IUCN 
distribution, and information about functional traits from PanTHEIRA [122]. However, we recommend using the patch-landscape approach for studies of terrestrial mammals, since those animals do not exclusively inhabit forest fragments.

As some variation exists between species included within the same ecospecies, or even within some taxonomic species (e.g., differences in fruit consumption; see Strier [123] and Carvalho et al. [124]), the use of values of diet for ecospecies may have prevented the detection of some relationships in the present study. Nevertheless, various species included in this study did not have specific data for these variables. More detailed studies should be conducted whenever these data are available in a species-specific, or even site-specific, basis.

Finally, conservation planning for primates communities should consider both the regional context and the fragment size. At the regional level, the economic, social, political, and cultural context can have different influences on the matrix. For example, post-conflict areas can modify the land uses and make some areas within biodiversity hotspots more sensitive for primates [125]. For species with broad geographic range distributed in more than one sub-region (e.g., Ateles belzebuth, present in the Amazon and Orinoco; Alouatta belzebul, in the Amazon and Atlantic Forest; and Alouatta palliata in Mesoamerica and Tumbes-Chocó-Magdalena) [126], we need to consider that deforestation rates are different among countries and forest types, and the amount of remaining natural habitat changes from one region to another $[127,128]$. At the fragment level, however, it is necessary to conduct forest restoration programs aimed at increasing the current forest extension and fragment sizes or connecting remaining forest patches. The creation of new protected areas, even in fragmented landscapes, is also an important conservation strategy, as evidence suggest that in the Neotropical region, protected areas are efficient in retaining larger primates. Considering these aspects could help to prevent the loss of primates—one of the most charismatic animals—during Earth's sixth mass extinction.

Supplementary Materials: The following are available online at http://www.mdpi.com/1424-2818/11/5/83/s1, Figure S1: Moran's I correlograms of the residuals of each model, Figure S2: Proportion of matrix attributes among eight sub-regions in the Neotropics, Table S1: Species composition of each forest fragment, Table S2: Proportion of dietary items for each ecospecies, Table S3: List of 97 fragments used in the analysis.

Author Contributions: Conceptualization, B.R.C.-R., R.R.H. and J.J.d.T.; methodology, B.R.C.-R. and R.R.H.; formal analysis, B.R.C.-R. and R.R.H.; writing—original draft preparation, B.R.C.-R.; writing-review and editing, R.R.H. and J.J.d.T.

Funding: B.R.C.-R. is supported by a PhD scholarship from the Federal Agency for Support and Evaluation of Graduate Education ("Coordenação de Aperfeiçoamento de Pessoal de Nível Superior" -CAPES).

Acknowledgments: The authors are grateful to Karen Mustin for contributions to a previous version of this manuscript, and Xyomara Carretero-Pinzón for revision of the English of this manuscript. We thank the two anonymous reviewers for their comments, which significantly improved the manuscript.

Conflicts of Interest: The authors declare no conflict of interest and this study does not need approval of any institution and/or governmental agency that regulates research with animals.

\section{References}

1. Barnosky, A.D.; Matzke, N.; Tomiya, S.; Wogan, G.O.U.; Swartz, B.; Quental, T.B.; Marshall, C.; McGuire, J.L.; Lindsey, E.L.; Maguire, K.C.; et al. Has the Earth's sixth mass extinction already arrived? Nature 2011, 471, 51-57. [CrossRef] [PubMed]

2. Hansen, M.C.; Potapov, P.V.; Moore, R.; Hancher, M.; Turubanova, S.A.; Tyukavina, A.; Thau, D.; Stehman, S.V.; Goetz, S.J.; Loveland, T.R.; et al. High-resolution global maps of 21st-century forest cover change. Science 2013, 342, 850-853. [CrossRef]

3. Haddad, N.M.; Brudvig, L.A.; Clobert, J.; Davies, K.F.; Gonzalez, A.; Holt, R.D.; Lovejoy, T.E.; Sexton, J.O.; Austin, M.P.; Collins, C.D.; et al. Habitat fragmentation and its lasting impact on earth's ecosystems. Sci. Adv. 2015, 1, e1500052. [CrossRef] [PubMed]

4. Brockerhoff, E.G.; Jactel, H.; Parrotta, J.A.; Quine, C.P.; Sayer, J. Plantation forests and biodiversity: Oxymoron or opportunity? Biodivers. Conserv. 2008, 17, 925-951. [CrossRef] 
5. Laurance, W.F.; Goosem, M.; Laurance, S.G.W. Impacts of roads and linear clearings on tropical forests. Trends Ecol. Evol. 2009, 24, 659-669. [CrossRef]

6. Benchimol, M.; Venticinque, E.M. Responses of primates to landscape change in Amazonian land-bridge islands-a multi-scale analysis. Biotropica 2014, 46, 470-478. [CrossRef]

7. da Silva, L.G.; Ribeiro, M.C.; Hasui, E.; da Costa, C.A.; da Cunha, R.G.T. Patch size, functional isolation, visibility and matrix permeability influences Neotropical primate occurrence within highly fragmented landscapes. PLoS ONE 2015, 10, e0114025. [CrossRef] [PubMed]

8. Borges-Matos, C.; Aragón, S.; da Silva, M.N.F.; Fortin, M.J.; Magnusson, W.E. Importance of the matrix in determining small-mammal assemblages in an Amazonian forest-savanna mosaic. Biol. Conserv. 2016, 204, 417-425. [CrossRef]

9. Fahrig, L.; Merriam, G. Conservation of fragmented populations. Conserv. Biol. 1994, 8, 50-59. [CrossRef]

10. Ricketts, T.H. The matrix matters: Effective isolation in fragmented landscapes. Am. Nat. 2001, 158, 87-99. [CrossRef]

11. Tischendorf, L.; Fahrig, L. On the usage and measurement of landscape connectivity. Oikos 2000, 90, 7-19. [CrossRef]

12. Arroyo-Rodríguez, V.; Fahrig, L. Why is a landscape perspective important in studies of primates? Am. J. Primatol. 2014, 76, 901-909. [CrossRef]

13. Dirzo, R.; Young, H.S.; Galetti, M.; Ceballos, G.; Isaac, N.J.B.; Collen, B. Defaunation in the anthropocene. Science 2014, 345, 401-406. [CrossRef] [PubMed]

14. Asensio, N.; Arroyo-Rodríguez, V.; Dunn, J.C.; Cristóbal-Azkarate, J. Conservation value of landscape supplementation for Howler Monkeys living in forest patches. Biotropica 2009, 41, 768-773. [CrossRef]

15. Pozo-Montuy, G.; Serio-Silva, J.C.; Chapman, C.A.; Bonilla-Sánchez, Y.M. Resource use in a landscape matrix by an arboreal primate: Evidence of supplementation in Black Howlers (Alouatta pigra). Int. J. Primatol. 2013, 34, 714-731. [CrossRef]

16. Estrada, A.; Garber, P.A.; Rylands, A.B.; Roos, C.; Fernandez-Duque, E.; DiFiore, A.; Nekaris, K.A.I.; Nijman, V.; Heymann, E.W.; Lambert, J.E.; et al. Impending extinction crisis of the world's primates: Why primates matter. Sci. Adv. 2017, 3, e1600946. [CrossRef] [PubMed]

17. de Assumpção, C.T. Cebus apella and Brachyteles arachnoides (Cebidae) as potential pollinators of Mabea fistulifera (Euphorbiaceae). J. Mammal. 1981, 62, 386-388. [CrossRef]

18. Janson, C.H.; Terborgh, J.; Emmons, L.H. Non-flying mammals as pollinating agents in the Amazonian forest. Biotropica 1981, 13, 1-6. [CrossRef]

19. Chapman, C.A.; Bonnell, T.R.; Gogarten, J.F.; Lambert, J.E.; Omeja, P.A.; Twinomugisha, D.; Wasserman, M.D.; Rothman, J.M. Are primates ecosystem engineers? Int. J. Primatol. 2013, 34, 1-14. [CrossRef]

20. Andresen, E.; Arroyo-Rodríguez, V.; Ramos-Robles, M. Primate seed dispersal: Old and new challenges. Int. J. Primatol. 2018, 39, 443-465. [CrossRef]

21. Stevenson, P.R. The abundance of large Ateline monkeys is positively associated with the diversity of plants regenerating in Neotropical forests. Biotropica 2011, 43, 512-519. [CrossRef]

22. Cormier, L.A. Preliminary review of Neotropical primates in the subsistence and symbolism of indigenous lowland South American peoples. Ecol. Environ. Anthropol. 2006, 2, 14-32.

23. Peres, C.A.; Emilio, T.; Schietti, J.; Desmoulière, S.J.M.; Levid, T. Dispersal limitation induces long-term biomass collapse in overhunted Amazonian forests. Proc. Natl. Acad. Sci. USA 2016, 113, 892-897. [CrossRef] [PubMed]

24. Michalski, F.; Peres, C.A. Anthropogenic determinants of primate and carnivore local extinctions in a fragmented forest landscape of southern Amazonia. Biol. Conserv. 2005, 124, 383-396. [CrossRef]

25. Boyle, S.A.; Smith, A.T. Can landscape and species characteristics predict primate presence in forest fragments in the Brazilian Amazon? Biol. Conserv. 2010, 143, 1134-1143. [CrossRef]

26. Arroyo-Rodríguez, V.; Mandujano, S.; Benítez-Malvido, J. Landscape attributes affecting patch occupancy by Howler Monkeys (Alouatta palliata mexicana) at Los Tuxtlas, Mexico. Am. J. Primatol. 2008, 70, 69-77. [CrossRef]

27. Carretero-Pinzón, X.; Defler, T.R.; McAlpine, C.A.; Rhodes, J.R. The influence of landscape relative to site and patch variables on primate distributions in the Colombian Llanos. Landsc. Ecol. 2017, 32, 883-896. [CrossRef] 
28. Puig-Lagunes, A.A.; Canales-Espinosa, D.; Rangel-Negrín, A.; Dias, P.A.D. The influence of spatial attributes on fragment occupancy and population structure in the Mexican Mantled Howler (Alouatta palliata mexicana). Int. J. Primatol. 2016, 37, 656-670. [CrossRef]

29. Nuñez-Iturri, G.; Olsson, O.; Howe, H.F. Hunting reduces recruitment of primate-dispersed trees in Amazonian Peru. Biol. Conserv. 2008, 141, 1536-1546. [CrossRef]

30. Stevenson, P.R.; Aldana, A.M. Potential effects of Ateline extinction and forest fragmentation on plant diversity and composition in the Western Orinoco basin, Colombia. Int. J. Primatol. 2008, 29, 365-377. [CrossRef]

31. Calle-Rendón, B.R.; Peck, M.; Bennett, S.E.; Morelos-Juarez, C.; Alfonso, F. Comparison of forest regeneration in two sites with different primate abundances in Northwestern Ecuador. Rev. Biol. Trop. 2016, 64, 493-506. [CrossRef] [PubMed]

32. Gouveia, S.F.; Villalobos, F.; Dobrovolski, R.; Beltrão-Mendes, R.; Ferrari, S.F. Forest structure drives global diversity of primates. J. Anim. Ecol. 2014, 83, 1523-1530. [CrossRef]

33. Millennium Ecosystem Assessment. Ecosystems and Human Well-Being: Biodiversity Synthesis; Island Press: Washington, DC, USA, 2005.

34. Harcourt, A.H.; Doherty, D.A. Species-area relationships of primates in tropical forest fragments: A global analysis. J. Appl. Ecol. 2005, 42, 630-637. [CrossRef]

35. Gibbons, M.A.; Harcourt, A.H. Biological correlates of extinction and persistence of primates in small forest fragments: A global analysis. Trop. Conserv. Sci. 2009, 2, 388-403. [CrossRef]

36. Benchimol, M.; Peres, C.A. Anthropogenic modulators of species-area relationships in Neotropical primates: A continental-scale analysis of fragmented forest landscapes. Divers. Distrib. 2013, 19, 1339-1352. [CrossRef]

37. Altrichter, M.; Boaglio, G.I. Distribution and relative abundance of peccaries in the Argentine Chaco: Associations with human factors. Biol. Conserv. 2004, 116, 217-225. [CrossRef]

38. Nagy-Reis, N.B.; Estevo, C.A.; Setz, E.Z.F.; Ribeiro, M.C.; Chiarello, A.G.; Nichols, J.D. Relative importance of anthropogenic landscape characteristics for Neotropical frugivores at multiple scales. Anim. Conserv. 2017, 20, 520-531. [CrossRef]

39. Carrillo, E.; Wong, G.; Cuarón, A.D. Monitoring mammal populations in Costa Rican protected areas under different hunting restrictions. Conserv. Biol. 2000, 14, 1580-1591. [CrossRef]

40. Rovero, F.; Mtui, A.; Kitegile, A.; Jacob, P.; Araldi, A.; Tenan, S. Primates decline rapidly in unprotected forests: Evidence from a monitoring program with data constraints. PLoS ONE 2015, 10, e0118330. [CrossRef]

41. Oklander, L.I.; Kowalewski, M.M.; Corach, D. Genetic consequences of habitat fragmentation in Black-and-Gold Howler (Alouatta caraya) populations from northern Argentina. Int. J. Primatol. 2010, 31, 813-832. [CrossRef]

42. Chaves, P.B.; Alvarenga, C.S.; Possamai, C.B.; Dias, L.G.; Boubli, J.P.; Strier, K.B.; Mendes, S.L.; Fagundes, V. Genetic diversity and population history of a critically endangered primate, the Northern Muriqui (Brachyteles hypoxanthus). PLoS ONE 2011, 6, e20722. [CrossRef]

43. Benchimol, M.; Peres, C.A. Predicting primate local extinctions within "real-world" forest fragments: A pan-neotropical analysis. Am. J. Primatol. 2014, 76, 289-302. [CrossRef] [PubMed]

44. Gascon, C.; Lovejoy, T.E.; Bierregaard, R.O.; Malcolm, J.R.; Stouffer, P.C.; Vasconcelos, H.L.; Laurance, W.F.; Zimmerman, B.; Tocher, M.; Borges, S. Matrix habitat and species richness in tropical forest remnants. Biol. Conserv. 1999, 91, 223-229. [CrossRef]

45. Uehara-Prado, M.; Fernandes, J.O.; Bello, A.M.; Machado, G.; Santos, A.J.; Vaz-de-Mello, F.Z.; Freitas, A.V.L. Selecting terrestrial arthropods as indicators of small-scale disturbance: A first approach in the Brazilian Atlantic Forest. Biol. Conserv. 2009, 142, 1220-1228. [CrossRef]

46. Rylands, A.B.; Mittermeier, R.A.; Silva Jr, J.S. Neotropical primates: Taxonomy and recently described species and subspecies. Int. Zoo Yearb. 2012, 46, 11-24. [CrossRef]

47. Kierulff, M.C.; Santos, G.R.; Canale, G.R.; Guidorizzi, C.E.; Cassano, C.R. The use of camera-traps in a survey of the Buff-Headed Capuchin Monkey, Cebus xanthosternos. Neotrop. Primates 2004, 12, 56-59.

48. Bowler, M.T.; Tobler, M.W.; Endress, B.A.; Gilmore, M.P.; Anderson, M.J. Estimating mammalian species richness and occupancy in tropical forest canopies with arboreal camera traps. Remote Sens. Ecol. Conserv. 2017, 3, 146-157. [CrossRef]

49. Brito, D.; Grelle, C.E.V. Estimating minimum area of suitable habitat and viable population size for the Northern Muriqui (Brachyteles hypoxanthus). Biodivers. Conserv. 2006, 15, 4197-4210. [CrossRef] 
50. Gestich, C.C.; Arroyo-Rodríguez, V.; Ribeiro, M.C.; da Cunha, R.G.T.; Setz, E.Z.F. Unraveling the scales of effect of landscape structure on primate species richness and density of Titi Monkeys (Callicebus nigrifrons). Ecol. Res. 2019, 34, 150-159. [CrossRef]

51. Barbosa, R.I.; Campos, C. Detection and geographical distribution of clearing areas in the savannas ('lavrado') of Roraima using Google Earth web tool. J. Geogr. Reg. Plan. 2011, 4, 122-136.

52. Laurance, W.F. Edge effects in tropical forest fragments: Application of a model for the design of nature reserves. Biol. Conserv. 1991, 57, 205-219. [CrossRef]

53. CEPF. The Biodiversity Hotspots: Version 2016.1. Critical Ecosystem Partnership Fund. Available online: http://www.cepf.net/resources/hotspots/Pages/default.aspx (accessed on 25 January 2017).

54. IBGE. Mapa de Biomas do Brasil: Primeira aproximação. Instituto Brasileiro de Geografia e Estatística. Available online: http://mapas.mma.gov.br/mapas/aplic/probio/datadownload.htm (accessed on 25 January 2017).

55. Rodríguez-Mahecha, J.V.; Salaman, P.; Jørgensen, P.; Consiglio, T.; Suárez, L.; Arjona, F.; Bensted-Smith, R. Tumbes-Chocó-Magdalena. In Hotspots Revisited: Earth's Biologically Richest and Most Endangered Terrestrial Ecoregions; Mittermeier, R.A., Gil, P.R., Hoffmann, M., Pilgrim, J., Brooks, T., Mittermeier, C.G., Lamoreux, J., da Fonseca, G.A.B., Eds.; CEMEX/Agrupación Sierra Madre: Mexico City, Mexico, 2004; pp. 80-84.

56. Da Fonseca, G.A.B.; Cavalcanti, R.; Rylands, A.; Paglia, A. Cerrado. In Hotspots Revisited: Earth's Biologically Richest and Most Endangered Terrestrial, Ecoregions; Mittermeier, R.A., Gil, P.R., Hoffmann, M., Pilgrim, J., Brooks, T., Mittermeier, C.G., Lamoreux, J., da Fonseca, G.A.B., Eds.; CEMEX/Agrupación Sierra Madre: Mexico City, Mexico, 2004; pp. 93-96.

57. Roesch, L.F.W.; Vieira, F.C.B.; Pereira, V.A.; Schünemann, A.L.; Teixeira, I.F.; Senna, A.J.T.; Stefenon, V.M. The Brazilian Pampa: A fragile biome. Diversity 2009, 1, 182-198. [CrossRef]

58. Oliveira, G.; Araújo, M.B.; Rangel, T.F.; Alagador, D.; Diniz-Filho, J.A.F. Conserving the Brazilian semiarid (Caatinga) biome under climate change. Biodivers. Conserv. 2012, 21, 2913-2926. [CrossRef]

59. Larrotta, L.F.; González, J.F.; Rodríguez, A. Primates en un Paisaje de los Montes de María, Colombia: Distribución y Estado Poblacional de Primates en la Ecorregión de Montes de María, Colombia; Editorial Académica Española: Saarbrücken, Germany, 2016.

60. Rodríguez-Mahecha, J.V.; Salaman, P.; Jørgensen, P.; Consiglio, T.; Forno, E.; Telesca, A.; Suárez, L.; Arjona, F.; Rojas, F.; Bensted-Smith, R.; et al. Tropical Andes. In Hotspots Revisited: Earth's Biologically Richest and Most Endangered Terrestrial, Ecoregions; Mittermeier, R.A., Gil, P.R., Hoffmann, M., Pilgrim, J., Brooks, T., Mittermeier, C.G., Lamoreux, J., da Fonseca, G.A.B., Eds.; CEMEX/Agrupación Sierra Madre: Mexico City, Mexico, 2004; pp. 73-79.

61. da Fonseca, G.A.B.; Rylands, A.; Paglia, A.; Mittermeier, R.A. Atlantic Forest. In Hotspots Revisited: Earth's Biologically Richest and Most Endangered Terrestrial Ecoregions; Mittermeier, R.A., Gil, P.R., Hoffmann, M., Pilgrim, J., Brooks, T., Mittermeier, C.G., Lamoreux, J., da Fonseca, G.A.B., Eds.; CEMEX/Agrupación Sierra Madre: Mexico City, Mexico, 2004; pp. 84-88.

62. Mittermeier, R.A.; Schipper, J.; Davidse, G.; Koleff, P.; Soberón, J.; Ramírez, M.; Goettsch, B.; Mittermeier, C.G. Mesoamerica. In Hotspots Revisited: Earth's Biologically Richest and Most Endangered Terrestrial, Ecoregions; Mittermeier, R.A., Gil, P.R., Hoffmann, M., Pilgrim, J., Brooks, T., Mittermeier, C.G., Lamoreux, J., da Fonseca, G.A.B., Eds.; CEMEX/Agrupación Sierra Madre: Mexico City, Mexico, 2004; pp. 103-112.

63. Daly, D.C.; Mitchell, J.D. Lowland vegetation of tropical South America - an overview. In Imperfect Balance: Landscape Transformations in the Pre-Columbian Americas; Lentz, D., Ed.; Columbia University Press: New York, NY, USA, 2000; pp. 391-454.

64. Santos-Filho, M.; Peres, C.A.; da Silva, D.J.; Sanaiotti, T.M. Habitat patch and matrix effects on small-mammal persistence in Amazonian forest fragments. Biodivers. Conserv. 2012, 21, 1127-1147. [CrossRef]

65. Hannibal, W.; da Cunha, N.L.; Figueiredo, V.V.; Rossi, R.F.; Cáceres, N.C.; Ferreira, V.L. Multi-scale approach to disentangle the small mammal composition in a fragmented landscape in central Brazil. J. Mammal. 2018, 99, 1455-1464. [CrossRef]

66. Muñoz, D.; Estrada, A.; Naranjo, E.; Ochoa, S. Foraging ecology of Howler Monkeys in a cacao (Theobroma cacao) plantation in Comalcalco, Mexico. Am. J. Primatol. 2006, 68, 127-142. [CrossRef]

67. Zeigler, S.L.; Neel, M.C.; Oliveira, L.; Raboy, B.E.; Fagan, W.F. Conspecific and heterospecific attraction in assessments of functional connectivity. Biodivers. Conserv. 2011, 20, 2779-2796. [CrossRef] 
68. Alba-Mejia, L.; Caillaud, D.; Montenegro, O.L.; Sánchez-Palomino, P.; Crofoot, M.C. Spatiotemporal interactions among three neighboring groups of free-ranging White-Footed Tamarins (Saguinus leucopus) in Colombia. Int. J. Primatol. 2013, 34, 1281-1297. [CrossRef]

69. Fahrig, L. Rethinking patch size and isolation effects: The habitat amount hypothesis. J. Biogeogr. 2013, 40, 1649-1663. [CrossRef]

70. Simard, M.; Pinto, N.; Fisher, J.B.; Baccini, A. Mapping forest canopy height globally with spaceborne lidar. J. Geophys. Res. 2011, 116, 1-12. [CrossRef]

71. NEO. Net Primary Productivity. NASA Earth Observations. Available online: https://neo.sci.gsfc.nasa.gov/ view.php?datasetId=MOD17A2_M_PSN (accessed on 7 March 2017).

72. Fick, S.E.; Hijmans, R.J. WorldClim 2: New 1-km spatial resolution climate surfaces for global land areas. Int. J. Climatol. 2017, 37, 4302-4315. [CrossRef]

73. IUCN. The IUCN Red List of Threatened Species: Version 2017-1. Available online: http://www.iucnredlist. org/ (accessed on 22 February 2017).

74. Hawes, J.E.; Peres, C.A. Ecological correlates of trophic status and frugivory in Neotropical primates. Oikos 2014, 123, 365-377. [CrossRef]

75. Peres, C.A.; Janson, C.H. Species coexistence, distribution, and environmental determinants of Neotropical primate richness: A community-level zoogeographic analysis. In Primate Communities; Fleagle, J.G., Janson, C.H., Reed, K.E., Eds.; Cambridge University Press: Cambridge, UK, 1999; pp. 55-74.

76. AWP. All the World's Primates. Available online:. Available online: https://alltheworldsprimates.org/Home. aspx (accessed on 16 May 2019).

77. Pinheiro, J.; Bates, D.; DebRoy, S.; Sarkar, D.; Heisterkamp, S.; van Willigen, B.; EISPACK; R-core. Package 'nlme' - Linear and Nonlinear Mixed Effects Models. R Package Version 3.1-137. Available online: https: //cran.r-project.org/web/packages/nlme/index.html (accessed on 23 October 2018).

78. Zuur, A.F.; Ieno, E.N.; Walker, N.J.; Saveliev, A.A.; Smith, G.M. Mixed Effects Models and Extensions in Ecology with R; Springer Science: New York, NY, USA, 2009.

79. Bartón, K. Pachage 'MuMIn'-Multi-Model Inference. R Package Version 1.42.1. Available online: https: //cran.r-project.org/web/packages/MuMIn/index.html (accessed on 23 October 2018).

80. Bjornstad, O.N.; Cai, J. Package 'ncf'—Spatial Covariance Functions. R Package Version 1.2-6. Available online: https://cran.r-project.org/web/packages/ncf/index.html (accessed on 23 October 2018).

81. Nakagawa, S.; Schielzeth, H. A general and simple method for obtaining $\mathrm{R}^{2}$ from generalized linear mixed-effects models. Methods Ecol. Evol. 2013, 4, 133-142. [CrossRef]

82. R Core Team. R: A Language and Environment for Statistical Computing; R Foundation for Statistical Computing: Vienna, Austria, 2018; Available online: https://www.r-project.org/ (accessed on 22 October 2018).

83. Keinath, D.A.; Doak, D.F.; Hodges, K.E.; Prugh, L.R.; Fagan, W.; Sekercioglu, C.H.; Buchart, S.H.M.; Kauffman, M. A global analysis of traits predicting species sensitivity to habitat fragmentation. Glob. Ecol. Biogeogr. 2017, 26, 115-127. [CrossRef]

84. Arroyo-Rodríguez, V.; Mandujano, S. Forest fragmentation modifies habitat quality for Alouatta palliata. Int. J. Primatol. 2006, 27, 1079-1096. [CrossRef]

85. Laurance, W.F.; Nascimento, H.E.M.; Laurance, S.G.; Andrade, A.; Ribeiro, J.E.L.S.; Giraldo, J.P.; Lovejoy, T.E.; Condit, R.; Chave, J.; Harms, K.E.; et al. Rapid decay of tree-community composition in Amazonian forest fragments. Proc. Nat. Acad. Sci. USA 2006, 103, 19010-19014. [CrossRef] [PubMed]

86. Laurance, W.F.; Delamônica, P.; Laurance, S.G.; Vasconcelos, H.L.; Lovejoy, T.E. Rainforest fragmentation kills big trees. Nature 2000, 404, 836. [CrossRef]

87. Laurance, W.F.; Nascimento, H.E.M.; Laurance, S.G.; Andrade, A.C.; Fearnside, P.M.; Ribeiro, J.E.L.; Capretz, R.L. Rain forest fragmentation and the proliferation of successional trees. Ecology 2006, 87, 469-482. [CrossRef] [PubMed]

88. Ripple, W.J.; Wolf, C.; Newsome, T.M.; Hoffmann, M.; Wirsing, A.J.; McCauleyg, D.J. Extinction risk is most acute for the world's largest and smallest vertebrates. Proc. Nat. Acad. Sci. USA 2017, 114, 10678-10683. [CrossRef]

89. Benítez-Malvido, J.; Martínez-Ramos, M. Impact of forest fragmentation on understory plant species richness in Amazonia. Conserv. Biol. 2003, 17, 389-400. [CrossRef]

90. Geldmann, J.; Barnes, M.; Coad, L.; Craigie, I.D.; Hockings, M.; Burgess, N.D. Effectiveness of terrestrial protected areas in reducing habitat loss and population declines. Biol. Conserv. 2013, 161, 230-238. [CrossRef] 
91. Gray, C.L.; Hill, S.L.L.; Newbold, T.; Hudson, L.N.; Börger, L.; Contu, S.; Hoskins, A.J.; Ferrier, S.; Purvis, A.; Scharlemann, J.P.W. Local biodiversity is higher inside than outside terrestrial protected areas worldwide. Nat. Commun. 2016, 7, 12306. [CrossRef] [PubMed]

92. Poorter, L.; Bongers, F. Leaf traits are good predictors of plant performance across 53 rain forest species. Ecology 2006, 87, 1733-1743. [CrossRef]

93. Morellato, L.P.C.; Haddad, C.F.B. Introduction: The Brazilian Atlantic Forest. Biotropica 2000, 32, 786-792. [CrossRef]

94. Mandujano, S.; Escobedo-Morales, L.A. Population viability analysis of Howler Monkeys (Alouatta palliata mexicana) in a highly fragmented landscape in Los Tuxtlas, Mexico. Trop. Conserv. Sci. 2008, 1, 43-62. [CrossRef]

95. Pyritz, L.W.; Büntge, A.B.S.; Herzog, S.K.; Kessler, M. Effects of habitat structure and fragmentation on diversity and abundance of primates in tropical deciduous forests in Bolivia. Int. J. Primatol. 2010, 31, 796-812. [CrossRef] [PubMed]

96. Riba-Hernández, P.; Stoner, K.E. Massive destruction of Symphonia globulifera (Clusiaceae) flowers by Central American Spider Monkeys (Ateles geoffroyi). Biotropica 2005, 37, 274-278. [CrossRef]

97. Stevenson, P.R.; Guzmán-Caro, D.C. Nutrient transport within and between habitats through seed dispersal processes by Woolly Monkeys in North-Western Amazonia. Am. J. Primatol. 2010, 72, 992-1003. [CrossRef]

98. Galetti, M.; Bovendorp, R.S.; Guevara, R. Defaunation of large mammals leads to an increase in seed predation in the Atlantic forests. Glob. Ecol. Conserv. 2015, 3, 824-830. [CrossRef]

99. Schweiger, O.; Maelfait, J.P.; van Wingerden, W.; Hendrickx, F.; Billeter, R.; Speelmans, M.; Augenstein, I.; Aukema, B.; Aviron, S.; Bailey, D.; et al. Quantifying the impact of environmental factors on arthropod communities in agricultural landscapes across organizational levels and spatial scales. J. Appl. Ecol. 2005, 42, 1129-1139. [CrossRef]

100. Hendrickx, F.; Maelfait, J.P.; van Wingerden, W.; Schweiger, O.; Speelmans, M.; Aviron, S.; Augenstein, I.; Billeter, R.; Bailey, D.; Bukacek, R.; et al. How landscape structure, land-use intensity and habitat diversity affect components of total arthropod diversity in agricultural landscapes. J. Appl. Ecol. 2007, 44, 340-351. [CrossRef]

101. Gonzalez-Kirchner, J.P.; Sainz, M.M. Primates hunting by Guaymi Amerindians in Costa Rica. Hum. Evol. 1998, 13, 15-19. [CrossRef]

102. Parathian, H.E.; Maldonado, A.M. Human-nonhuman primate interactions amongst Tikuna people: Perceptions and local initiatives for resource management in Amacayacu in the Colombian Amazon. Am. J. Primatol. 2010, 72, 855-865. [CrossRef]

103. Ruivo, E.B.; Wormell, D. The international conservation programme for the White-Footed Tamarin Saguinus leucopus in Colombia. Int. Zoo Yearb. 2012, 46, 46-55. [CrossRef]

104. Canale, G.R.; Kierulff, M.C.M.; Chivers, D.J. A critically endangered capuchin monkey (Sapajus xanthosternos) living in a highly fragmented hotspot. In Primates in Fragments: Complexity and Resilience; Marsh, L.K., Chapman, C.A., Eds.; Springer: New York, NY, USA, 2013; pp. 299-311.

105. Buss, G.; Queiroz, H.; Melo, F.R.; Talebi, M.; Jerusalinsky, L. Ka'apor Capuchin. In Primates in Peril: The World's 25 Most Endangered Primates 2016-2018; Schwitzer, C., Mittermeier, R.A., Rylands, A.B., Chiozza, F., Williamson, E.A., Macfie, E.J., Wallis, J., Cotton, A., Eds.; IUCN SSC Primate Specialist Group (PSG), International Primatological Society (IPS), Conservation International (CI), and Bristol Zoological Society: Arlington, VA, USA, 2017; pp. 88-90.

106. Benchimol, M.; Peres, C.A. Widespread forest vertebrate extinctions induced by a mega hydroelectric dam in lowland Amazonia. PLoS ONE 2015, 10, e0129818. [CrossRef] [PubMed]

107. Jones, I.L.; Bunnefeld, N.; Jump, A.S.; Peres, C.A.; Dent, D.H. Extinction debt on reservoir land-bridge islands. Biol. Conserv. 2016, 199, 75-83. [CrossRef]

108. Zilihona, I.J.E.; Niemelä, J.; Nummelin, M. Effects of a hydropower plant on Coleopteran diversity and abundance in the Udzungwa Mountains, Tanzania. Biodivers. Conserv. 2004, 13, 1453-1464. [CrossRef]

109. Paetzold, A.; Yoshimura, C.; Tockner, K. Riparian arthropod responses to flow regulation and river channelization. J. Appl. Ecol. 2008, 45, 894-903. [CrossRef]

110. Dray, S.; Pélissier, R.; Couteron, P.; Fortin, M.J.; Legendre, P.; Peres-Neto, P.R.; Bellier, E.; Bivand, R.; Blanchet, F.G.; De Cáceres, M.; et al. Community ecology in the age of multivariate multiscale spatial analysis. Ecol. Monogr. 2012, 82, 257-275. [CrossRef] 
111. Condit, R.; Pitman, N.; Leigh, E.G., Jr.; Chave, J.; Terborgh, J.; Foster, R.B.; Núñez, P.; Aguilar, S.; Valencia, R.; Villa, G.; Muller-Landau, H.C.; et al. Beta-diversity in tropical forest trees. Science 2002, 295, 666-669. [CrossRef]

112. Gardner, T.A.; Barlow, J.; Chazdon, R.; Ewers, R.M.; Harvey, C.A.; Peres, C.A.; Sodhi, N.S. Prospects for tropical forest biodiversity in a human-modified world. Ecol. Lett. 2009, 12, 561-582. [CrossRef]

113. Denis, T.; Héraul, B.; Brunaux, O.; Guitet, S.; Richard-Hansen, C. Weak environmental controls on the composition and diversity of medium and large-sized vertebrate assemblages in Neotropical rain forests of the Guiana Shield. Divers. Distrib. 2018, 24, 1545-1559. [CrossRef]

114. Donati, G.; Santini, L.; Eppley, T.M.; Arrigo-Nelson, S.J.; Balestri, M.; Boinski, S.; Bollen, A.; Bridgeman, L.L.; Campera, M.; Carrai, V.; et al. Low levels of fruit nitrogen as drivers for the evolution of Madagascar's primate communities. Sci. Rep. 2017, 7, 14406. [CrossRef]

115. Harcourt, A.H. Latitude and latitudinal extent: A global analysis of the Rapoport effect in a tropical mammalian taxon: Primates. J. Biogeogr. 2000, 27, 1169-1182. [CrossRef]

116. Purvis, A.; Gittleman, J.L.; Cowlishaw, G.; Mace, G.M. Predicting extinction risk in declining species. Proc. R. Soc. Lond. 2000, 267, 1947-1952. [CrossRef]

117. Estrada, A.; Coates-Estrada, R. Tropical rain forest fragmentation and wild populations of primates at Los Tuxtlas, Mexico. Int. J. Primatol. 1996, 17, 759-783. [CrossRef]

118. Palacios-Silva, R.; Mandujano, S. Modelando la dinámica de ocupación de parches de selva por primates en un paisaje fragmentado de Los Tuxtlas, México. In Avances en el Estudio de los Mamíferos de México II; Lorenzo, C., Espinoza, E., Ortega, J., Eds.; Asociación Mexicana de Mastozoología, A.C.: Mexico City, México, 2008; pp. 493-509.

119. Williams-Guillén, K.; Hagell, S.; Otterstrom, S.; Spehar, S.; Gómez, C. Primate populations in fragmented tropical dry forest landscapes in southwestern Nicaragua. In Primates in Fragments: Complexity and Resilience; Marsh, L.K., Chapman, C.A., Eds.; Springer: New York, NY, USA, 2013; pp. 105-120.

120. Myers, N.; Mittermeier, R.A.; Mittermeier, C.G.; da Fonseca, G.A.B.; Kent, J. Biodiversity hotspots for conservation priorities. Nature 2000, 403, 853-858. [CrossRef]

121. Olson, D.M.; Dinerstein, E. The global 200: Priority ecoregions for global conservation. Ann. Mo. Bot. Gard. 2002, 89, 199-224. [CrossRef]

122. Jones, K.E.; Bielby, J.; Cardillo, M.; Fritz, S.A.; O’Dell, J.; Orme, C.D.L.; Safi, K.; Sechrest, W.; Boakes, E.H.; Carbone, C.; et al. PanTHERIA: A species-level database of life history, ecology, and geography of extant and recently extinct mammals. Ecology 2009, 90, 2648. [CrossRef]

123. Strier, K.B. Diet in one group of Woolly Spider Monkeys, or Muiriquis (Brachyteles arachnoides). Am. J. Primatol. 1991, 23, 113-126. [CrossRef]

124. Carvalho, O.; Ferrari, S.F.; Strier, K.B. Diet of a Muriqui group (Brachyteles arachnoides) in a continuous primary forest. Primates 2004, 45, 201-204. [CrossRef] [PubMed]

125. Calle-Rendón, B.R.; Moreno, F.; Hilário, R.R. Vulnerability of mammals to land-use changes in Colombia's post-conflict era. Nat. Conserv. 2018, 29, 79-92. [CrossRef]

126. IUCN. The IUCN Red List of Threatened Species: Version 2018-2. Available online: http://www.iucnredlist. org/. (accessed on 24 November 2018).

127. Armenteras, D.; Espelta, J.M.; Rodríguez, N.; Retana, J. Deforestation dynamics and drivers in different forest types in Latin America: Three decades of studies (1980-2010). Glob. Environ. Chang. 2017, 46, 139-147. [CrossRef]

128. Dinerstein, E.; Olson, D.; Joshi, A.; Vynne, C.; Burgess, N.D.; Wikramanayake, E.; Hahn, N.; Palminteri, S.; Hedao, P.; Noss, R.; et al. An ecoregion-based approach to protecting half the terrestrial realm. BioScience 2017, 67, 534-545. [CrossRef] [PubMed]

(C) 2019 by the authors. Licensee MDPI, Basel, Switzerland. This article is an open access article distributed under the terms and conditions of the Creative Commons Attribution (CC BY) license (http://creativecommons.org/licenses/by/4.0/). 